Jurnal Kejuruteraan SI 1(1) 2018: 37-46

http://dx.doi.org/10.17576/jkukm-2018-si1(1)-06

\title{
Recent Perspectives and Crucial Challenges on Unitized Regenerative Fuel Cell (URFC)
}

\author{
(Perspektif Terkini dan Cabaran Kritikal mengenai Sel Fuel Regeneratif Terunit (URFC)) \\ Ahmad Mohamad Pauzi, Umi Azmah Hasran*, Sahriah Basri, Nabila A. Karim \\ Fuel Cell Institute \\ Universiti Kebangsaan Malaysia, Malaysia.
}

\begin{abstract}
Renewable sources of energy are becoming increasingly popular in recent years. The idea of using alternative energy that utilizes renewable sources is to slowly replace our dependence on fossil fuels. Conventional fossil fuels are not viable due to the fact that they are predominantly unsustainable over the long run. Furthermore, pollution will be reduced through the use of cleaner and more environmentally friendly renewable energy. Polymer electrolyte membrane fuel cell (PEMFC), which utilizes hydrogen as fuel, has a high potential as an alternative power generator. The unitized regenerative fuel cell (URFC) is a type of PEMFC that can perform both in charge mode (as a fuel cell) and discharge mode (as an electrolyzer). This review looks into the recent researches on the structure and different components of the URFC. In particular, emphasis is placed on bifunctional electrodes. Recent development in URFC research has produced a more stable bifunctional electrode with improved energy efficiency and overall stability and durability. Various works have been carried out to replace Pt as the electrocatalyst, including the use of graphene as a low cost non-metal graphene-based electrocatalyst. Electrocatalyst support also plays an important role in increasing conductivity while reducing the catalyst resistance to corrosion. The technological challenges and limitations of the URFC system are also discussed in this review.
\end{abstract}

Keywords: Regenerative Fuel Cell; Water Electrolysis; Gas Diffusion Layer; Bifunctional Electrode

ABSTRAK

Sumber tenaga yang boleh diperbaharui menjadi semakin popular dalam beberapa tahun kebelakangan ini. Idea untuk tenaga alternatif yang menggunakan sumber tenaga yang boleh diperbaharui ini adalah bagi menggantikan pergantungan kita terhadap bahan api fosil secara perlahan-lahan. Bahan api fosil konvensional tidak berdaya maju kerana tidak dapat kekal digunakan dalam jangka panjang, oleh itu sumber tenaga yang bersih dan boleh diperbaharui diperlukan. Pada masa yang sama, pencemaran juga boleh dikurangkan melalui penggunaan tenaga boleh diperbaharui yang bersih dan lebih mesra alam. Sel fuel membran elektrolit polimer (PEMFC), yang menggunakan hidrogen sebagai fuel, mempunyai potensi tinggi sebagai penjana kuasa alternatif. Sel Sel Fuel Regeneratif Terunit (URFC) adalah sejenis PEMFC yang boleh menjalankan kedua-dua mod caj (sebagai sel fuel) dan mod discaj (sebagai alat elektrolisis). Kajian ulasan ini melihat kajian terbaru mengenai struktur dan komponen yang berlainan bagi URFC. Secara khususnya, penekanan diberikan kepada peranan mangkin dwifungsi untuk prestasi sistem URFC. Perkembangan terbaru dalam penyelidikan URFC telah menghasilkan elektrod dwifungsi yang lebih stabil dengan kecekapan tenaga yang lebih baik serta kestabilan dan ketahanan keseluruhan. Pelbagai usaha telah dijalankan untuk menggantikan Pt sebagai elektromangkin, termasuk penggunaan bahan berasaskan grafin sebagai mangkin bukan logam yang rendah kos. Penyokong elektromangkin juga memainkan peranan yang penting dalam meningkatkan kekonduksian di samping mengurangkan rintangan mangkin kepada kakisan. Cabaran dan batasan teknologi sistem URFC juga dibincangkan dalam kertas ulasan ini.

Kata kunci: Sel Fuel Regeneratif; Elektrolisis air; Lapisan Resapan Gas; Elektrod Dwifungsi

\section{INTRODUCTION}

Nowadays, there is a major challenge in finding a feasible renewable energy source to replace the widely used fossil fuels. Alternative energy source is desperately required by the increasing demand for energy due to the explosive development of industrialization in many countries. Climate change and global warming due to the excessive emission of pollutants have also been a warning trigger to migrate towards an emission free and green source of renewable energy.
A polymer electrolyte membrane fuel cell (PEMFC) is a fuel cell type that can be an alternative power generator as PEMFC is able to continuously operate at high current densities, low temperature. PEMFC is also tolerant to shock and vibration as well as having a compact and durable form that makes it the currently preferred commercially viable fuel cell type (Guerrero et al. 2015). The performance of PEMFC is bounded by polarization, temperature, pressure and gas stream composition. 
Therefore, researches on the effects of designs and operating conditions of the cell potential is important to reduce these setbacks (Kamarudin et al. 2007). Membranes used for PEMFC are mostly related to ionomers, i.e. perfluorosulfonic acid ionomers (PFSA) such as Nafion ${ }^{\circledR}$ or Aquivion ${ }^{\circledR}$, due to their excellent chemical and electrochemical stability (Assumma et al. 2015). Among other commercially available PFSA ionomers that exhibit high proton conductivity and chemical stability are Flemion, DAM-3G, Fumion, Gore Select, Dow, 3M and Aciplex (Campagne et al. 2013).

The reactions occurring in the polymer electrolyte membrane electrolyzer (PEMEL) are as shown in Equations $1-3$. The reactant (water) is oxidized into oxygen, protons and electrons at the anodic reactive site by the catalyst. Meanwhile, the hydrogen ions conducted through the polymer electrolyte membrane (PEM) and the electrons that travel through the external circuit are combined at the cathodic reactive site to form gaseous hydrogen (Rahim et al. 2016). The operating principle of PEMEL is the opposite of PEMFC, as illustrated in Figure 1.

Anode:

Cathode:

$$
\mathrm{H}_{2} \mathrm{O} \rightarrow 2 \mathrm{H}^{+}+\mathrm{O}_{2}+2 \mathrm{e}^{-}
$$$$
\text { Overall Reaction: } \mathrm{H}_{2} \mathrm{O}(\mathrm{l}) \rightarrow \mathrm{H}_{2}(\mathrm{~g})+\mathrm{O}_{2}(\mathrm{~g})
$$

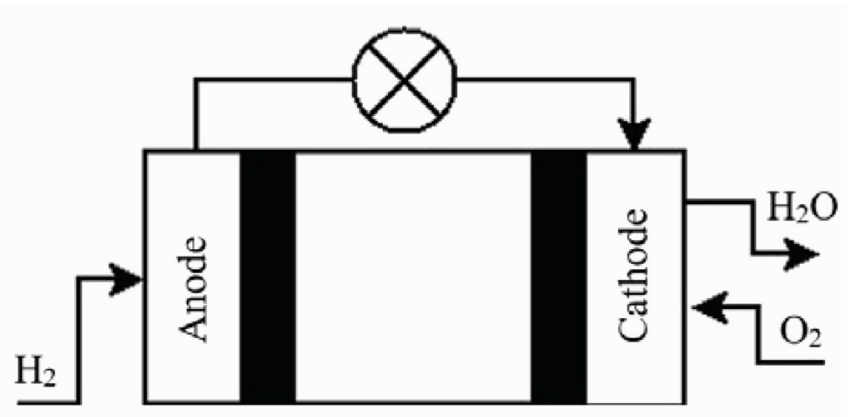

FIGURE 1. Concept of a PEMFC

The combination of PEMEL and PEMFC into URFC is an efficient method of storing energy and reducing the sophistication of the two separate systems. A typical structure of a regenerative fuel cell (RFC) consists of an electrolyzer (EL) that converts water into hydrogen and oxygen using electricity, a fuel cell (FC) that utilizes hydrogen as fuel to generate electricity, and a tank for storing the oxygen and hydrogen gases used in the process (Guarnieri et al. 2015). Figure 2 illustrates the concept of a RFC.

A unitized regenerative fuel cell (URFC) is a type of fuel cell that can produce clean energy efficiently as it is an electrochemical energy conversion and storage system that can effectively generate electricity in FC mode as well as split the water into hydrogen and oxygen in EL mode. The reactions occurring in the URFC in EL and FC modes are as shown in Equations 4-9 and illustrated in Figure 3.

On the anode side (the oxidation electrode), water is supplied and the molecules are dissociated into oxygen, protons, and electrons through oxygen evolution reaction (OER) during EL mode, whereas hydrogen molecules experience hydrogen oxidation reaction (HOR), in which they are dissociated into protons and electrons, during FC mode. On the cathode side (the reduction electrode), incoming protons and electrons from the oxygen electrode experience hydrogen evolution reaction (HER) to produce hydrogen during EL mode, whereas oxygen molecules experience oxygen reduction reaction (ORR) to produce water during FC mode. Therefore, a bifunctional electrode is required for the URFC operation (Swider-Lyons and Campbell 2013).

Other types of water electrolysis technology are also currently being researched. The silicon oxide electrolyzer cells (SOEC) are capable of operating at a very high temperature range of $700-1000^{\circ} \mathrm{C}$., whereas an alkaline electrolyzer (AEL) that uses sodium hydroxide $(\mathrm{NaOH})$ and potassium hydroxide $(\mathrm{KOH})$ as electrolytes is inefficient in terms of energy production but applicably cost effective (Lee et al. 2016).

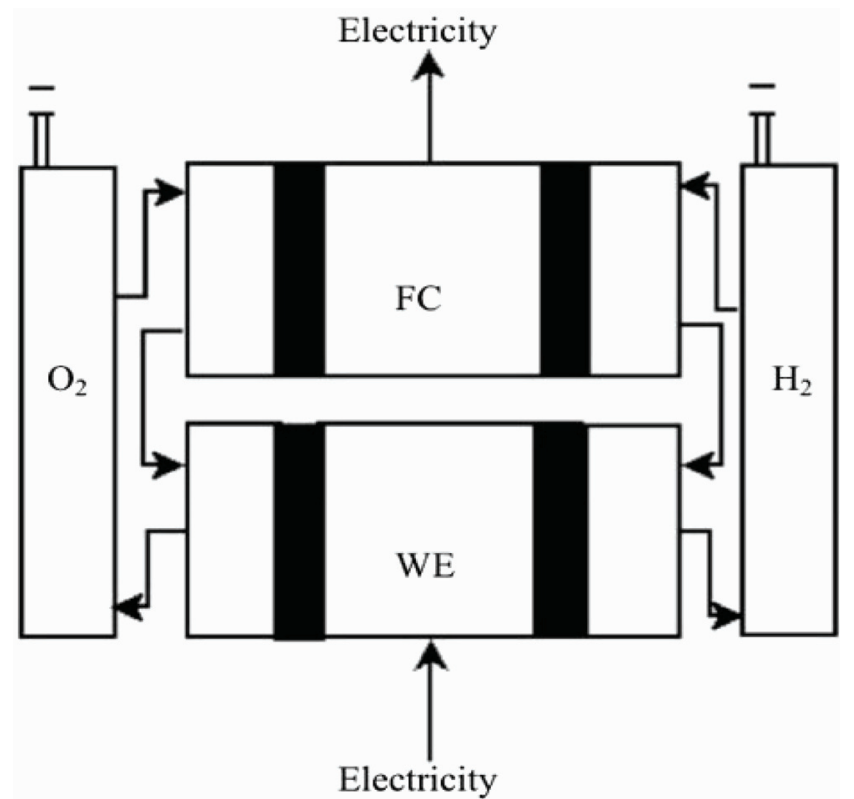

FIGURE 2. Concept of a RFC

- $\quad$ EL mode

$\begin{array}{ll}\text { Anode: } & \mathrm{H}_{2} \mathrm{O} \rightarrow 2 \mathrm{H}^{+}+\mathrm{O}_{2}+2 \mathrm{e}^{-} \\ \text {Cathode: } & 2 \mathrm{H}^{+}+2 \mathrm{e}^{-} \rightarrow \mathrm{H}_{2} \\ \text { Overall Reaction: } & \mathrm{H}_{2} \mathrm{O}(\mathrm{l}) \rightarrow \mathrm{H}_{2}(\mathrm{~g})+\mathrm{O}_{2}(\mathrm{~g})\end{array}$

- $\quad$ FC mode

$$
\begin{array}{ll}
\text { Anode: } & \mathrm{H}_{2} \rightarrow 2 \mathrm{H}^{+}+2 \mathrm{e}^{-} \\
\text {Cathode: } & \mathrm{O}_{2}+2 \mathrm{H}^{+}+2 \mathrm{e}^{-} \rightarrow \mathrm{H}_{2} \mathrm{O} \\
\text { Overall Reaction: } & \mathrm{H}_{2}+\mathrm{O}_{2} \rightarrow \mathrm{H}_{2} \mathrm{O}
\end{array}
$$

\section{TECHNOLOGICAL CHALLENGES ON URFC}

\section{WATER MANAGEMENT}

The electrode is designed to be purposely flooded during EL mode. Conversely, the electrode for the FC mode is designed to repel water in order to increase the mobility of $\mathrm{H}_{2}$ and $\mathrm{O}_{2}$ to reach the catalyst surface. Development of flow channels 


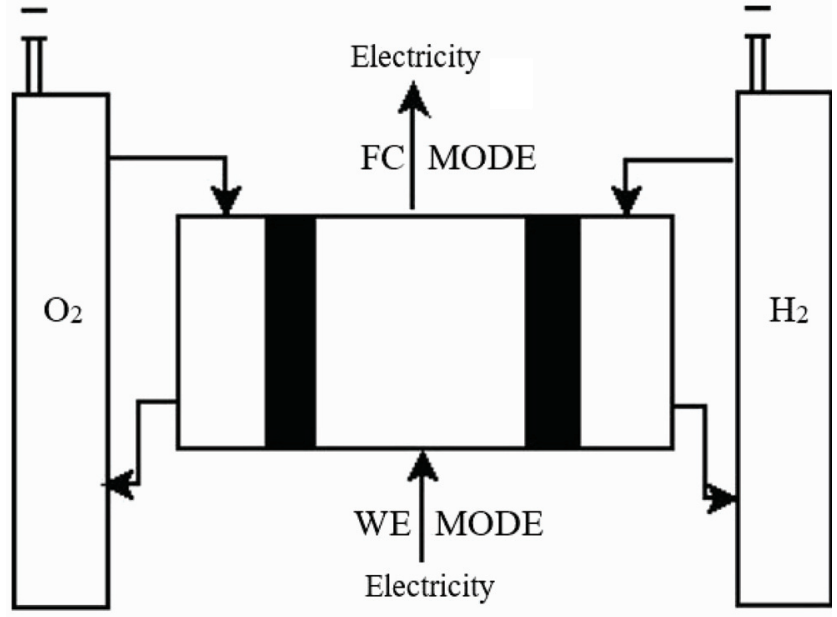

FIGURE 3. Concept of unitized regenerative fuel cell (URFC)

for the bipolar plates (BPPs) is crucial for the management of oxygen, fuel and water in the fuel cell system. Hwang et al. (2013) concluded that the parallel and serpentine-dual flow designs for BPPs can improve fuel cell efficiency and electrolysis performance. They used PTFE-treated Ti-felt GDL in the oxygen electrode and this also contributed to the improvement of water discharge during FC mode.

Apart from that, Lele et al. (2014) introduced a prototype design of UV-catalyzed porous polymer wicks, which improved the water flooding by diverting the water produced towards the water storage chamber. This passive water management was able to reduce the roundtrip efficiency loss and was found to be a better strategy compared to the active method that resulted in parasitic loss and a decrease in system efficiency.

$\cos T$

One of the most crucial disadvantages of the URFC system is the cost of the materials used. The high cost is associated with the use of rare platinum $(\mathrm{Pt})$ metal on the surface of bifunctional electrocatalyst and the cost of the polymer electrolyte in the cell region (Fuentes et al. 2014; García et al. 2013; Vesborg and Jaramillo 2012).
Figure 4 describes the analysis of the cost status of fuel cell stack at 500,000 systems per year as compared to the cost in the 2020 targets. This shows that the development of technology for the URFC system can potentially lower the cost of the overall system by using different materials and overcome the durability issue currently faced by the system.

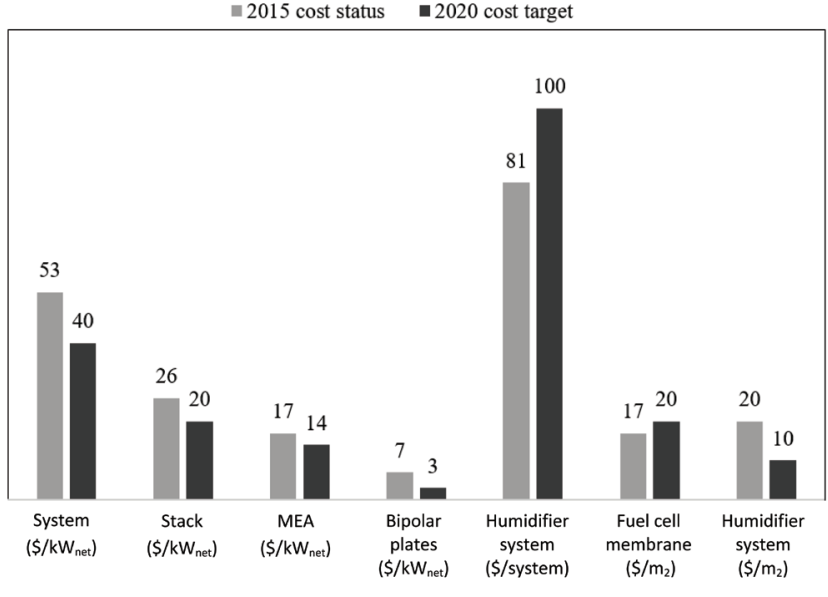

FIGURE 4. Projected cost of a fuel cell system in \$USD (Marcinkoski et al. 2015)

\section{STRUCTURAL SETUP OF URFC STACK}

Nafion, a widely used PEM for hydrogen fuel cells, provides high proton conductivity and low gas crossover (Antolini 2014). The electrolyte is essentially a conductive polymer membrane that acts as a barrier for the fuel and electrons but a conductor for protons (Boutsika et al. 2016). Nafion is expensive and does not work well in high temperature and low humidity. The use of hydrocarbon-based PEM increases the proton conductivity but also increases the chance of water flooding. Therefore, it is generally required to reinforce the composite PEM with excellent mechanical properties. The performance of different PEM composites is as summarized in Table 1.

TABLE 1. Performance of PEM composites in PEMFC

\begin{tabular}{|c|c|c|}
\hline Author & Polymer electrolyte membrane & Performance \\
\hline Liu et al. (2016) & Carbonitride $\mathrm{Ti}_{3} \mathrm{C}_{2} \mathrm{~T}_{\mathrm{x}}$ filler & $\begin{array}{l}\text { Increased proton conduction and overall hydrogen fuel cell } \\
\text { performance }\end{array}$ \\
\hline Oh et al. (2014) & $\begin{array}{l}\text { Boron nitride nanoflakes (BNNFs) } \\
\text { nano-filler }\end{array}$ & $\begin{array}{l}\text { Improved durability of PEMFC contributed by the excellent } \\
\text { mechanical strength of boron nitride. }\end{array}$ \\
\hline Baker et al. (2014) & $\begin{array}{l}\text { Nafion with Ceria coated multiwall carbon } \\
\text { nanotubes MWCNTs }\end{array}$ & $\begin{array}{l}\text { Increased mechanical stability and membrane durability in } \\
\text { PEMFC system }\end{array}$ \\
\hline Miyahara et al. (2012) & $\begin{array}{l}\text { Sulfonated polybenzophenone/poly } \\
\text { (arylene ether) block copolymers }\end{array}$ & $\begin{array}{l}\text { Increased proton conductivity and durability at low humidity } \\
(\mathrm{RH}=30 \%)\end{array}$ \\
\hline Kim et al. (2012) & $\begin{array}{l}\mathrm{H}_{3} \mathrm{PO}_{4} \text {-doped cross-linked benzoxazine - } \\
\text { benzimidazole copolymer membrane }\end{array}$ & $\begin{array}{l}\text { Increased conductivity under anhydrous condition and overall } \\
\text { fuel cell performance }\end{array}$ \\
\hline
\end{tabular}


For the gas diffusion layer (GDL), its functions consist of transporting the reactant gas from the flow channel to the catalyst layer, draining the water from the catalyst layer to the flow channel, and maintaining a constant moisture condition of the membrane at low humidity (Park et al. 2015). The BPPS deliver the reactants to the active catalyst layer through the GDL and the subsequent porous electrode while maintaining a minimum pressure drop (Kahraman and Orhan 2017). The advantages and limitations of using different types of GDL and BPPs are summarized in Table 2 and Table 3, respectively.

TABLE 2. Performance of URFC with different GDL

\begin{tabular}{|c|c|c|c|}
\hline Author & GDL & Advantage & Limitation \\
\hline Hwang et al. (2012) & Titanium (Ti)-felt & $\begin{array}{l}\text { The Ti-powder loading increase the } \\
\text { effectiveness of water flooding prevention } \\
\text { in wet condition }(\mathrm{RH}=100 \%)\end{array}$ & $\begin{array}{l}\text { Not effective under dry } \\
\text { condition }(\mathrm{RH}=66 \%)\end{array}$ \\
\hline Ito et al. (2015) & $\begin{array}{l}\text { Through-plane } \\
\text { Polytetrafluoroethylene } \\
\text { distribution in Ti-felt }\end{array}$ & $\begin{array}{l}\text { Current density increased and improve } \\
\text { liquid water discharge in wet condition } \\
(\mathrm{RH}=100 \%)\end{array}$ & - \\
\hline Huang et al. (2012) & $\begin{array}{l}\text { Conventional carbon substrate } \\
\text { as GDL \& Iridium-titanium } \\
\text { nitride (Ir-TiN) as MPL }\end{array}$ & $\begin{array}{l}\text { Reduced carbon corrosion during water } \\
\text { electrolysis mode }\end{array}$ & - \\
\hline Lee and $\mathrm{Kim}(2014)$ & $\begin{array}{l}\mathrm{IrO}_{2} / \mathrm{Pt} / \mathrm{IrO}_{2} \text { layered-electrode } \\
\text { structure: Pt sandwiched between } \\
\text { two } \mathrm{IrO}_{2} \text { layers in contact with a } \\
\text { membrane carbon-based GDL }\end{array}$ & $\begin{array}{l}\text { The electrochemical carbon corrosion is } \\
\text { decreased and cyclic performance is } \\
\text { significantly increased }\end{array}$ & - \\
\hline Hwang et al. (2013) & Titanium (Ti)-felt & $\begin{array}{l}\text { Performance in FC mode increased in the } \\
\text { dry condition as PTFE contents increase } \\
\text { in FC mode }\end{array}$ & $\begin{array}{l}\text { Flooding increased as } \\
\text { PTFE contents increased }\end{array}$ \\
\hline Alvar et al. (2014) & $\begin{array}{l}\text { Wet coating of carbon paper with } \\
\mathrm{Nb} \text {-doped } \mathrm{TiO}_{2}\end{array}$ & $\begin{array}{l}\text { Increased stability towards oxidation at } \\
\text { the oxygen electrode }\end{array}$ & \\
\hline
\end{tabular}

TABLE 3. Performance of URFC with different BPPs

\begin{tabular}{|c|c|c|c|}
\hline Author & Bipolar Plates & Advantage & Limitation \\
\hline Zhang et al. (2012) & $\begin{array}{l}\text { Honeycomb-like nanocomposite } \\
\text { Ti-Ag-N Films }\end{array}$ & $\begin{array}{l}\text { Showed excellent conductivity by the } \\
\text { Ag nanoparticles and increased corrosion } \\
\text { resistant. }\end{array}$ & - \\
\hline St. John et al. (2010) & $\begin{array}{l}\text { Au-Nanoparticle Polyaniline } \\
\text { Hybrid Coating }\end{array}$ & $\begin{array}{l}\text { AuNPs-PANI showed excellent corrosion } \\
\text { resistance at } 0.61 \mathrm{~V} \text { SHE and stability in } \\
\text { cathodic PEFC environment }\end{array}$ & - \\
\hline Lin et al. (2014) & $\begin{array}{l}\text { SS304 Stainless Steel and Titanium } \\
\text { Coated with Alternate Layers of } \\
\text { TiN and ZrN }\end{array}$ & $\begin{array}{l}\text { Improved corrosion resistance by } \\
243 \text { times }\end{array}$ & - \\
\hline Hwang et al. (2013) & Serpentine-single flow field design & $\begin{array}{l}\text { Improves the performance of FC mode } \\
\text { electrolysis mode. }\end{array}$ & Deteriorate during the \\
\hline Lin et al. (2013) & $\begin{array}{l}\text { SS304 substrate coated with } \\
(\mathrm{Ti}, \mathrm{Zr}) \mathrm{N} \text { thin films }\end{array}$ & $\begin{array}{l}\text { Improved corrosion resistance by } \\
215 \text { times }\end{array}$ & - \\
\hline
\end{tabular}

The results show that outstanding performance and increased corrosion resistance contribute to the improved efficiency of the URFC system. Studies into light weight and low cost bipolar plate materials are also actively carried out, such as the optimization work on conductive polymer composites by Irmayani and Suherman 2017. Regardless, further research is needed to find alternative BPP materials for a more favorable URFC system cost and performance.

The catalyst layer in URFC is crucial as it essentially exists to provide continuous pathways, i.e., an efficient path for the transport of protons, steady path of the pore network for the reactants/products and water withdrawal, and also a constant path for the conduction of electrons between the catalyst layer and the current collector (Zamel 2016). Some of the main setbacks of using PEMFC are the low durability and high cost of the electrocatalysts used, especially $\mathrm{Pt}$ (Lobato et al. 2016). Pt has been widely used as the primary catalyst, which also contributes to the excessive cost of PEMFC (Ebrahimi et al. 2016). 


\section{URFC CATALYST}

URFC BIFUNCTIONAL HYDROGEN ELECTRODE (BHE)

Pt has been widely used as the main component in BHE. However, the use of non-Pt-based metal is preferred despite its lesser performance as a substitute for the electrocatalysts due to the scarcity and exorbitant cost of Pt.

Wang et al. 2016 suggested the idea of using an electrochemical catalyst of Phosphorus (P) and Nitrogen (N) dual-doped cobalt-based carbon nanofibers (Co-N-PCNFs) using an electrospinning method. The doping of N/P atoms in the Co-based CNFs increases the electrocatalytic performance, showing low onset potential of $-0.216 \mathrm{~V}$ and a stable current density of $10 \mathrm{~mA} \mathrm{~cm}{ }^{-2}$ at the potential of $-0.248 \mathrm{~V}$ in the HER.

Ding et al. (2015) employed the use of nickel-decorated carbon nanofibers via an electrospinning method. A Ni/C nanofiber hybrid with $8 \%$ Nickel (II) nitrate hexahydrate $\left(\mathrm{Ni}\left(\mathrm{NO}_{3}\right)_{2}-6 \mathrm{H}_{2} \mathrm{O}\right)$ was prepared. The membrane exhibited low overpotential of $-0.17 \mathrm{~V}$ and high current density of $3.05 \mathrm{~mA} \mathrm{~cm}^{-2}$ at overpotential $\eta=200 \mathrm{mV}$.

Huan et al. (2016) utilized nickel bis(diphosphine) complex $\left.\left[\mathrm{Ni}\left(\mathrm{P}_{2}^{\mathrm{R}} \mathrm{N}^{\mathrm{R}^{\prime}}\right)_{2}\right)_{2}\right]^{2+}$ in $0.5 \mathrm{M} \mathrm{H}_{2} \mathrm{SO}_{4}$ Aq. electrolyte attached on a multi-wall carbon nanotubes (MWCNTs) for bidirectional and reversible hydrogen evolution. They found that $\mathrm{Ni}$-based electrode was $\sim 35 \%$ less active for the hydrogen oxidation at $85^{\circ} \mathrm{C}$ and hydrogen production by $\sim 20 \%$. This cost-effective, molecular-engineered nanomaterial is able to transcend the conventional Pt electrodes but further research is needed to improve the long-term stability for the hydrogen oxidation.

\section{URFC BIFUNCTIONAL OXYGEN ELECTRODE (BOE)}

Currently, Pt in its reduced form is the best catalyst for oxidation-reduction reaction. However, it is not suitable for OER and therefore a different mixture of $\mathrm{Pt}, \mathrm{Ir}, \mathrm{Ru}, \mathrm{IrO}_{2}$ or $\mathrm{RuO}_{2}$, and other compounds have been utilized as a bifunctional oxygen electrode (Yim et al. 2005). The oxygen electrode is responsible for both the oxygen reduction and evolution reaction. The oxygen electrode of choice should possess high catalytic activity, long-term durability, high electronic conductivity as well as being cost efficient. Currently, the oxygen electrode is only limited to using noble metal catalyst, which is Pt in its reduced form (Wang et al. 2016). The performance of various bifunctional electrodes is summarized in Table 4.

Various researches have been carried out to replace $\mathrm{Pt}$ as the electrocatalyst, including the use of graphene. Mao et al. (2014) identified N-doped crumpled graphene-CoO (Cobalt oxide) as the OER bifunctional electrocatalyst. The overpotential of the OER study showed $\sim 0.34 \mathrm{~V}$, which is the smallest reported for a Co-based OER catalyst.

Ye et al. (2018) employed PtRuIr nanoclusters as the bifunctional electrocatalyst for the OER and ORR. The PtRuIr electrocatalyst showed superior active catalytic activity, specifically for the $10 \mathrm{~mol} \%$ of Ir that exhibited the highest electrocatalytic activity.
Ioroi et al. (2001) studied the use of iridium oxide/ platinum electrocatalyst as a substitute for the conventional Pt catalyst. It was found that the fuel cell performance was marginally degraded but showed an increase in water electrolysis performance.

Tian et al. (2014) investigated the use of Chemical Vapor Deposition (CVD) method to fabricate a novel N-doped graphene $(\mathrm{NG})$ with a single-walled carbon nanotube hybrid (NGSH). It was found that there is an increase in the OER and ORR of oxygen activity comparable to a $\mathrm{Pt} / \mathrm{C}$ catalyst. This in turns demonstrates high ORR activity and also better durability and resistance to crossover effect.

Lin et al. 2013 used pyrolysis to fabricate a NG as an alternative cost-effective and facile method. The study discussed how an immense anodic current exists when electric potential is applied between $-0.6 \mathrm{~V}$ and $0.8 \mathrm{~V}$, revealing the OER at the NG surface. Further testing showed that the current increased when the potential was extended to $1.0 \mathrm{~V}$.

Jahan et al. (2013) suggested that the graphene oxide (GO) is incorporated with copper-centered metal organic framework composite $(\mathrm{Cu}-\mathrm{MOF})$ as a tri-functional catalyst for ORR, OER, and HER. It was found that in PEMFC testing, the GO-incorporated $\mathrm{Cu}-\mathrm{MOF}$ composite delivered $76 \%$ higher current density as compared to the commercial Pt. Based on the power density curve, they obtained a maximum power density of $145 \mathrm{~mW} \mathrm{~cm}^{-2}$ for the Pt catalyst and $110.5 \mathrm{~mW}$ $\mathrm{cm}^{-2}$ for the GO-incorporated $\mathrm{Cu}-\mathrm{MOF}$.

Unni et al. (2015) investigated the use of graphene nanotube as an electrocatalyst derived from single-walled carbon nanohorns (SWCNH) containing thin layers of graphene nanotube with iron oxide nanoparticles (FeGNT). It was found that FeGNT showed a $750 \mathrm{~m}^{2} \mathrm{~g}^{-1}$ surface area and assisted the distribution of Fe-Nx and quaternary N-based activation centers, providing stability towards ORR in acidic and alkaline media. The PEMFC performance at the cathode

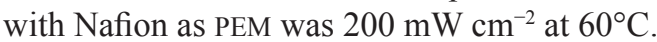

\section{ELECTROCATALYST SUPPORT}

A suitable electrocatalyst support increases the surface area for catalyst to be dispersed on, thus reducing the loading of metal catalyst. Additionally, the support controls wettability and increases conductivity while reducing its resistance to corrosion. Carbon black is not suitable in the application of URFC as a support material since the material is easily corroded at high voltages during EL mode. Numerous researches have been carried out to find a suitable electrocatalyst support. Table 5 summarizes the compilation of electrocatalyst supports previously studied. Titanium carbide and nitride are shown to be superior to the conventional Pt-based catalyst (Fuentes et al. 2014; García et al. 2013; Roca-Ayats et al. 2014). Iridium oxide compounds were fabricated in different methods and revealed higher OER and ORR activity compared to $\mathrm{Pt} / \mathrm{C}$ catalyst (Kim et al. 2015; Kong et al. 2012a). Additionally, antimony-doped tin dioxide shows promising stability and increased conductivity (Cruz et al. 2012; Gurrola et al. 2013). 
TABLE 4. The performance of bifunctional electrodes in URFC

\begin{tabular}{|c|c|c|c|c|c|c|c|}
\hline References & BOE & $\mathrm{T}\left({ }^{\circ} \mathrm{C}\right)$ & $\begin{array}{c}\text { Onset } \\
\text { Potential } \\
\text { (V) }\end{array}$ & $\begin{array}{c}\text { OER Activity } \\
\text { Overpotential (V) }\end{array}$ & ORR Activity & Electrolyte & Stability \\
\hline Ye et al. (2018) & $\begin{array}{l}\text { PtRuIr } \\
\text { nanoclusters }\end{array}$ & 25 & - & $63.48 \mathrm{~mA} \mathrm{~cm}^{-2}$ & $53.68 \mathrm{~mW} \mathrm{~cm}{ }^{-2}$ & $\begin{array}{l}\text { Nafion }(5 \mathrm{wt} \% \\
45 \mathrm{mg} \mathrm{cm}{ }^{-3}, \\
\text { DuPont) }\end{array}$ & - \\
\hline Mao et al. (2014) & $\begin{array}{l}\mathrm{N} \text {-doped crumpled } \\
\text { graphene-CoO } \\
\text { (cobalt oxide) }\end{array}$ & 25 & $\sim 0.90$ & $\begin{array}{l}\sim 0.34 @ 10 \mathrm{~mA} \\
\mathrm{~cm}^{-2} \text { Current } \\
\text { Density }\end{array}$ & - & $\begin{array}{l}5 \% \text { Nafion in } \\
\text { ethanol }\end{array}$ & $\begin{array}{l}\sim 13 \% \text { activity } \\
\text { loss after } 7000 \\
\text { Seconds (RDE) }\end{array}$ \\
\hline Tian et al. (2014) & $\begin{array}{l}\text { N-doped graphene } \\
\text { w/single-walled } \\
\text { carbon nanotube } \\
\text { hybrid (NGSH) }\end{array}$ & 25 & 0.88 & $\begin{array}{l}1.63 @ 10 \mathrm{~mA} \mathrm{~m}^{-2} \\
\text { Current Density }\end{array}$ & $\begin{array}{l}2.6 \mathrm{~mA} \mu \mathrm{g}_{\mathrm{N}}{ }^{-1} \\
\text { Current Density }\end{array}$ & $\begin{array}{l}\text { Nafion (\% wt } \% \\
\text { water solution) }\end{array}$ & $\begin{array}{l}\sim 8 \%(7.9) \\
\text { Relative } \\
\text { current loss } \\
\text { Chronoam- } \\
\text { perometric } \\
\text { response) after } \\
16000 \mathrm{~s} @ \\
1600 \mathrm{rpm}\end{array}$ \\
\hline Lin et al. (2013) & $\begin{array}{l}\text { NG-1000 (N } \\
\text { doping } 2.4 \text { at.\%) }\end{array}$ & 25 & - & - & $\begin{array}{l}-0.22 \mathrm{~V} \text { cathodic } \\
\text { current }\end{array}$ & $\begin{array}{l}\text { Nafion }(0.05 \\
\text { wt } \%)\end{array}$ & - \\
\hline Jahan et al. (2013) & $\begin{array}{l}\text { GO-incorporated } \\
\mathrm{Cu}-\mathrm{MOF}\end{array}$ & 25 & -0.202 & 1.54 & -0.21 & $5 \mathrm{wt} \%$ Nafion & - \\
\hline Ioroi et al. (2001) & Pt-IrO & 80 & - & $\begin{array}{l}51 \% \text { at } 500 \mathrm{~mA} \\
\mathrm{~cm}^{-2}\end{array}$ & & Nafion 115 & - \\
\hline
\end{tabular}

TABLE 5. Electrocatalyst support performance

\begin{tabular}{|c|c|c|}
\hline Author & Electrocatalyst support & Performance \\
\hline Won et al. 2018 & $\mathrm{Ti}_{4} \mathrm{O}_{7}$ & $\begin{array}{l}\mathrm{Ti}_{4} \mathrm{O}_{7} \text { showed increased OER and ORR; Better roundtrip efficiency than } \\
\mathrm{Pt} / \mathrm{C} \& \mathrm{Pt} / \mathrm{Ti}_{4} \mathrm{O}_{7} \text { support. }\end{array}$ \\
\hline Roca-Ayats et al. (2014) & $\mathrm{TiC}, \mathrm{TiCN} \& \mathrm{TiN}$ & TiCN support showed highest activity towards OER \& ORR. \\
\hline Roh et al. (2016) & $\mathrm{SiO}_{2}-\mathrm{SO}_{3} \mathrm{H}$ & $\begin{array}{l}\text { Stability of the MEA and roundtrip efficiency increased compared to } \\
\text { Pt/C catalyst. }\end{array}$ \\
\hline Cruz et al. (2012) & Sb-doped $\mathrm{SnO}_{2}(\mathrm{ATO})$ & $\begin{array}{l}\text { ATO support showed promising stability with } 0.6 \mathrm{~V} \text { in PEMFC mode \& } \\
1.55 \mathrm{~V} \text { in PEMWE mode at } 80^{\circ} \mathrm{C} \text {. }\end{array}$ \\
\hline García et al. (2013) & $\mathrm{TiC} \& \mathrm{TiCN}$ & $\begin{array}{l}\text { PtIr/TiCN catalyst showed enhanced ORR activity \& stability rather than } \\
\text { PtIr/TiC. }\end{array}$ \\
\hline Pai and Tseng (2012) & Graphitized carbon & $\begin{array}{l}\text { Graphitized carbon showed an increase in stability \& roundtrip efficiency } \\
\text { compared to conventional carbon black. }\end{array}$ \\
\hline Gurrola et al. (2013) & Sb-doped $\mathrm{SnO}_{2}(\mathrm{ATO})$ & $\begin{array}{l}\text { ATO support showed enhanced stability \& conductivity compared to carbon } \\
\text { black Vulcan XC-72. }\end{array}$ \\
\hline Kim et al. (2017) & Crumpled rGO & $\begin{array}{l}\text { Heat-treated Pt-Ir/rGOs at } 600^{\circ} \mathrm{C} \text { showed increased ORR activity and } \\
\text { nearly identical OER polarization trend compared to } \mathrm{Pt} / \mathrm{C} \text {. }\end{array}$ \\
\hline Kong et al. 2015 & SBA-15 template $\left(\mathrm{s}-\mathrm{IrO}_{2}\right)$ & $\begin{array}{l}\mathrm{s}-\mathrm{IrO}_{2} \text { catalyst revealed to have enhanced OER catalytic behavior and } \\
\text { ORR efficiency rather than } \mathrm{Pt} / \text { commercial } \mathrm{IrO}_{2} \text {. }\end{array}$ \\
\hline Kim et al. (2015) & $\begin{array}{l}\mathrm{IrO}_{2} \text { fabricated by } \\
\text { flashlight irradiation }\end{array}$ & $\mathrm{Pt}-\mathrm{IrO}_{2}$ showed higher OER activity compared to $\mathrm{Pt} / \mathrm{C}$ catalyst. \\
\hline Kong et al. (2012b) & Porous $\mathrm{IrO}_{2}$ & $\begin{array}{l}\mathrm{Pt} / \text { porous- } \mathrm{IrO}_{2} \text { showed high OER \& ORR activity compared to } \mathrm{Pt} / \\
\text { commercial- } \mathrm{IrO}_{2} \text {. }\end{array}$ \\
\hline Fuentes et al. (2014) & $\mathrm{TiC}$ & $\begin{array}{l}\text { Supported Pt-Ir/TiC showed better kinetic current per mass than Ir-black \& } \\
\text { Pt-based catalyst; enhanced roundtrip efficiency }\end{array}$ \\
\hline
\end{tabular}




\section{FABRICATION METHODS}

There are a variety of fabrication methods that have been developed essentially aimed at reducing the fabrication cost and efficiently producing the components of the URFC system. Kong et al. (2012c) incorporated Adams fusion method to prepare $\operatorname{Irx}\left(\mathrm{IrO}_{2}\right) 10$-x composites catalyst support. This fast and efficient method provides oxides with a high specific area especially for the preparation of platinum oxide, ruthenium oxide, and other similar groups. Pai and Tseng (2012) developed an ultrasonic mixed technique process to fabricate a bifunctional graphitized carbon-supported $\mathrm{Pt}$ oxygen, producing fine Pt/graphite electrocatalyst in order to make it highly corrosion-resistant and stable.

Studies have also looked into the works of the catalyst layer application process. $\mathrm{Ng}$ et al. (2013) incorporated the use of the commercial anion exchange membrane (AEM) (Fumapem FAA-3, Fumatech) to fabricate their membrane electrode assembly (MEA). Lee and Kim (2014) suggested the use of catalyst-coated membrane (CCM) method to fabricate their MEA. Meanwhile, Ng et al. (2014) used the conventional catalyst-coated substrate (CCS) technique to synthesize their MEA. However, according to Ito et al. (2016), both CCS and CCM methods are suitable for MEA fabrication.

\section{CONCLUSION}

This review has carried out a comprehensive study on the development of the unitized regenerative fuel cell (URFC) system. The URFC system has a limitation that causes severe drawbacks towards the overall efficiency and this mainly concerns the degradation of the catalyst support, gas diffusion layer, and BPPs due to carbon corrosion during the water electrolysis mode. Therefore, this issue is critically important to be identified in future studies to improve the URFC performance. It was found that the low cost non-metal graphene-based electrocatalyst shows promising stability and performance in fuel cell applications. Moreover, TiC is potentially a good electrocatalyst support to reduce the amount of Pt loading in the fuel cell. However, further research is needed for the non-metal electrocatalyst and electrocatalyst support to ultimately become viable and efficient for its application in URFC.

\section{ACKNOWLEDGEMENT}

The authors gratefully acknowledge the financial support given for this work by the Ministry of Higher Education (Malaysia) research grant FRGS/1/2016/TK09/UKM/03/1 and the Malaysia Research University Grant (GUP-2016-039).

\section{REFERENCES}

Alvar, E. N., Zhou, B. \& Eichhorn, S. H. 2014. Oxidative treatment to improve coating and electrochemical stability of carbon fiber paper with niobium doped titanium dioxide sols for potential applications in fuel cells. Electrochimica Acta 132: 347-355.

Antolini, E. 2014. Iridium as catalyst and cocatalyst for oxygen evolution/reduction in acidic polymer electrolyte membrane electrolyzers and fuel cells. ACS Catalysis 4(5): 1426-1440.

Assumma, L., Nguyen, H. D., Iojoiu, C., Lyonnard, S., Mercier, R. \& Espuche, E. 2015. Effects of block length and membrane processing conditions on the morphology and properties of perfluorosulfonated poly(arylene ether sulfone) multiblock copolymer membranes for PEMFC. ACS Applied Materials \& Interfaces 7(25): 13808-13820.

Baker, A. M., Wang, L., Johnson, W. B., Prasad, A. K. \& Advani, S. G. 2014. Nafion membranes reinforced with ceria-coated multiwall carbon nanotubes for improved mechanical and chemical durability in polymer electrolyte membrane fuel cells. The Journal of Physical Chemistry C 118(46): 26796-26802.

Boutsika, L. G., Enotiadis, A., Nicotera, I., Simari, C., Charalambopoulou, G., Giannelis, E. P. \& Steriotis, T. 2016. Nafion ${ }^{\circledR}$ nanocomposite membranes with enhanced properties at high temperature and low humidity environments. International Journal of Hydrogen Energy 41(47): 22406-22414.

Campagne, B., David, G., Améduri, B., Jones, D. J., Rozière, J. \& Roche, I. 2013. Novel blend membranes of partially fluorinated copolymers bearing azole functions with sulfonated PEEK for PEMFC operating at low relative humidity: influence of the nature of the N-heterocycle. Macromolecules 46(8): 3046-3057.

Cruz, J. C., Rivas, S., Beltran, D., Meas, Y., Ornelas, R., Osorio-Monreal, G., Ortiz-Frade, L., Ledesma-García, J. \& Arriaga, L. G. 2012. Synthesis and evaluation of ATO as a support for $\mathrm{Pt}-\mathrm{IrO} 2$ in a unitized regenerative fuel cell. International Journal of Hydrogen Energy 37(18): 13522-13528.

Ding, Q., Liu, M., Miao, Y.-E., Huang, Y. \& Liu, T. 2015. Electrospun nickel-decorated carbon nanofiber membranes as efficient electrocatalysts for hydrogen evolution reaction. Electrochimica Acta 159: 1-7.

Ebrahimi, S., Roshandel, R. \& Vijayaraghavan, K. 2016. Power density optimization of PEMFC cathode with non-uniform catalyst layer by Simplex method and numerical simulation. International Journal of Hydrogen Energy 41(47): 22260-22273.

Fuentes, R. E., Colón-Mercado, H. R. \& Martínez-Rodríguez, M. J. 2014. Pt-Ir/TiC electrocatalysts for PEM fuel cell/ electrolyzer process. Journal of The Electrochemical Society 161(1): F77-F82.

García, G., Roca-Ayats, M., Lillo, A., Galante, J. L., Peña, M. A. \& Martínez-Huerta, M. V. 2013. Catalyst support effects at the oxygen electrode of unitized regenerative fuel cells. Catalysis Today 210: 67-74.

Guarnieri, M., Alotto, P. \& Moro, F. 2015. Modeling the performance of hydrogen-oxygen unitized regenerative 
proton exchange membrane fuel cells for energy storage. Journal of Power Sources 297: 23-32.

Guerrero, M. N., Cisneros Molina, M., Gervasio, D. \& Pérez Robles, J. F. 2015. Approaches to polymer electrolyte membrane fuel cells (PEMFCs) and their cost. Renewable and Sustainable Energy Reviews 52: 897-906.

Gurrola, M. P., Guerra-Balcázar, M., Álvarez-Contreras, L., Nava, R., Ledesma-García, J. \& Arriaga, L. G. 2013. High surface electrochemical support based on Sb-doped SnO 2. Journal of Power Sources 243: 826-830.

Huan, T. N., Jane, R. T., Benayad, A., Guetaz, L., Tran, P. D. \& Artero, V. 2016. Bio-inspired noble metal-free nanomaterials approaching platinum performances for $\mathrm{H}$ ${ }_{2}$ evolution and uptake. Energy \& Environmental Science 9(3): 940-947.

Huang, S.-Y., Ganesan, P., Jung, H.-Y. \& Popov, B. N. 2012. Development of supported bifunctional oxygen electrocatalysts and corrosion-resistant gas diffusion layer for unitized regenerative fuel cell applications. Journal of Power Sources 198: 23-29.

Hwang, C., Ito, H., Maeda, T., Nakano, A., Kato, A. \& Yoshida, T. 2013. Flow field design for a polymer electrolyte unitized reversible fuel cell. ECS Transactions 50(2): 787-794.

Hwang, C. M., Ishida, M., Ito, H., Maeda, T., Nakano, A., Kato, A. \& Yoshida, T. 2012. Effect of titanium powder loading in gas diffusion layer of a polymer electrolyte unitized reversible fuel cell. Journal of Power Sources 202: 108-113.

Ioroi, T., Kitazawa, N., Yasuda, K., Yamamoto, Y. \& Takenaka, H. 2001. IrO2-deposited Pt electrocatalysts for unitized regenerative polymer electrolyte fuel cells. Journal of Applied Electrochemistry 31(11): 1179-1183.

Irmayani \& Suherman, H. 2017. Optimization of internal mixing parameter on the electrical conductivity of Multiwall Carbon Nanotubes/Synthetic Graphite/Epoxy Nanocomposites for conductive polymer composites using Taguchi Method. Jurnal Kejuruteraan 29(2): 79-85.

Ito, H., Abe, K., Ishida, M., Hwang, C. M. \& Nakano, A. 2015. Effect of through-plane polytetrafluoroethylene distribution in a gas diffusion layer on a polymer electrolyte unitized reversible fuel cell. International Journal of Hydrogen Energy 40(46): 16556-16565.

Ito, H., Miyazaki, N., Ishida, M. \& Nakano, A. 2016. Efficiency of unitized reversible fuel cell systems. International Journal of Hydrogen Energy 41(13): 5803-5815.

Jahan, M., Liu, Z. \& Loh, K. P. 2013. A graphene oxide and copper-centered metal organic framework composite as a tri-functional catalyst for HER, OER, and ORR. Advanced Functional Materials 23(43): 5363-5372.

Kahraman, H. \& Orhan, M. F. 2017. Flow field bipolar plates in a proton exchange membrane fuel cell: Analysis \& modeling. Energy Conversion and Management 133: 363-384.
Kamarudin, S. K., Daud, W. R. W., Md. Som, A. \& Masdar, M. S. 2007. Conceptual design of 5kW PEM fuel cell stack. Jurnal Kejuruteraan 19: 43-54.

Kim, D.-H., Park, S.-H., Choi, J., Yi, M. H. \& Kim, H.S. 2015. Fabrication of iridium oxide nanoparticles supported on activated carbon powder by flashlight irradiation for oxygen evolutions. Materials Science and Engineering: B 201: 29-34.

Kim, I. G., Nah, I. W., Oh, I.-H. \& Park, S. 2017. Crumpled rGO-supported Pt-Ir bifunctional catalyst prepared by spray pyrolysis for unitized regenerative fuel cells. Journal of Power Sources 364: 215-225.

Kim, S.-K., Choi, S.-W., Jeon, W. S., Park, J. O., Ko, T., Chang, H. \& Lee, J.-C. 2012. Cross-linked benzoxazinebenzimidazole copolymer electrolyte membranes for fuel cells at elevated temperature. Macromolecules 45(3): 1438-1446.

Kong, F.-D., Liu, J., Ling, A.-X., Xu, Z.-Q., Wang, H.-Y. \& Kong, Q.-S. 2015. Preparation of IrO2 nanoparticles with SBA-15 template and its supported Pt nanocomposite as bifunctional oxygen catalyst. Journal of Power Sources 299: 170-175.

Kong, F.-D., Zhang, S., Yin, G.-P., Wang, Z.-B., Du, C.-Y., Chen, G.-Y. \& Zhang, N. 2012a. Electrochemical studies of $\mathrm{Pt} / \mathrm{Ir}-\mathrm{IrO}$, electrocatalyst as a bifunctional oxygen electrode. International Journal of Hydrogen Energy 37(1): 59-67.

Kong, F.-D., Zhang, S., Yin, G.-P., Zhang, N., Wang, Z.-B. \& Du, C.-Y. 2012b. Pt/porous-IrO 2 nanocomposite as promising electrocatalyst for unitized regenerative fuel cell. Electrochemistry Communications 14(1): 63-66.

Kong, F.-D., Zhang, S., Yin, G.-P., Zhang, N., Wang, Z.-B. \& Du, C.-Y. 2012c. Preparation of Pt/Irx $\left(\operatorname{IrO}_{2}\right) 10-x$ bifunctional oxygen catalyst for unitized regenerative fuel cell. Journal of Power Sources 210: 321-326.

Lee, B.-S., Park, H.-Y., Choi, I., Cho, M. K., Kim, H.-J., Yoo, S. J., Henkensmeier, D., Kim, J. Y., Nam, S. W., Park, S., Lee, K.-Y. \& Jang, J. H. 2016. Polarization characteristics of a low catalyst loading PEM water electrolyzer operating at elevated temperature. Journal of Power Sources 309: 127-134.

Lee, W. H. \& Kim, H. 2014. Optimization of electrode structure to suppress electrochemical carbon corrosion of gas diffusion layer for unitized regenerative fuel cell. Journal of The Electrochemical Society 161(6): F729-F733.

Lele, S. S., Sizemore, M. A. \& Fabris, D. 2014. Improved passive water management design for use in unitized regenerative fuel cells. ASME 2014 12th International Conference on Fuel Cell Science, Engineering and Technology collocated with the ASME 2014 8th International Conference on Energy Sustainability. American Society of Mechanical Engineers.

Lin, M.-T., Wan, C.-H. \& Wu, W. 2013. Comparison of corrosion behaviors between SS304 and Ti substrate coated with $(\mathrm{Ti}, \mathrm{Zr}) \mathrm{N}$ thin films as Metal bipolar plate 
for unitized regenerative fuel cell. Thin Solid Films 544: 162-169.

Lin, M.-T., Wan, C.-H. \& Wu, W. 2014. Enhanced corrosion resistance of SS304 stainless steel and titanium coated with alternate layers of $\mathrm{TiN}$ and $\mathrm{ZrN}$ in a simulated $\mathrm{O}_{2}$ rich environment of a unitized regenerative fuel cell. Int. J. Electrochem. Sci. 9: 7832-7845.

Lin, Z., Waller, G. H., Liu, Y., Liu, M. \& Wong, C.-P. 2013. Simple preparation of nanoporous few-layer nitrogendoped graphene for use as an efficient electrocatalyst for oxygen reduction and oxygen evolution reactions. Carbon 53: 130-136.

Liu, Y., Zhang, J., Zhang, X., Li, Y. \& Wang, J. 2016. $\mathrm{Ti}_{3} \mathrm{C}_{2} \mathrm{~T}_{x}$ filler effect on the proton conduction property of polymer electrolyte membrane. ACS Applied Materials \& Interfaces 8(31): 20352-20363.

Lobato, J., Zamora, H., Plaza, J., Cañizares, P. \& Rodrigo, M. A. 2016. Enhancement of high temperature PEMFC stability using catalysts based on Pt supported on $\mathrm{SiC}$ based materials. Applied Catalysis B: Environmental 198: 516-524

Mao, S., Wen, Z., Huang, T., Hou, Y. \& Chen, J. 2014. High-performance bi-functional electrocatalysts of 3D crumpled graphene-cobalt oxide nanohybrids for oxygen reduction and evolution reactions. Energy Environ. Sci. 7(2): 609-616.

Marcinkoski, J., Spendelow, J., Wilson,A. \& Papageorgopoulos, D. 2015. DOE hydrogen and fuel cells program record. https://www.hydrogen.energy.gov/pdfs/15015 fuel cell system cost 2015.pdf [28 June 2018].

Miyahara, T., Hayano, T., Matsuno, S., Watanabe, M. \& Miyatake, K. 2012. Sulfonated polybenzophenone/ poly(arylene ether) block copolymer membranes for fuel cell applications. ACS Applied Materials \& Interfaces 4(6): 2881-2884

Ng, J. W. D., Gorlin, Y., Hatsukade, T. \& Jaramillo, T. F. 2013. A precious-metal-free regenerative fuel cell for storing renewable electricity. Advanced Energy Materials 3(12): $1545-1550$.

Ng, J. W. D., Tang, M. \& Jaramillo, T. F. 2014. A carbon-free, precious-metal-free, high-performance $\mathrm{O}_{2}$ electrode for regenerative fuel cells and metal-air batteries. Energy \& Environmental Science 7(6): 2017.

Oh, K.-H., Lee, D., Choo, M.-J., Park, K. H., Jeon, S., Hong, S. H., Park, J.-K. \& Choi, J. W. 2014. Enhanced durability of polymer electrolyte membrane fuel cells by functionalized 2D boron nitride nanoflakes. ACS Applied Materials \& Interfaces 6(10): 7751-7758.

Pai, Y.-H. \& Tseng, C.-W. 2012. Preparation and characterization of bifunctional graphitized carbonsupported Pt composite electrode for unitized regenerative fuel cell. Journal of Power Sources 202: 28-34.

Park, J., Oh, H., Ha, T., Lee, Y. I. \& Min, K. 2015. A review of the gas diffusion layer in proton exchange membrane fuel cells: Durability and degradation. Applied Energy 155: 866-880
Rahim, A. H. A., Tijani, A. S., Kamarudin, S. K. \& Hanapi, S. 2016. An overview of polymer electrolyte membrane electrolyzer for hydrogen production: Modeling and mass transport. Journal of Power Sources 309: 56-65.

Roca-Ayats, M., García, G., Galante, J. L., Peña, M. A. \& Martínez-Huerta, M. V. 2014. Electrocatalytic stability of Ti based-supported $\mathrm{Pt}_{3} \mathrm{Ir}$ nanoparticles for unitized regenerative fuel cells. International Journal of Hydrogen Energy 39(10): 5477-5484.

Roh, S.-H., Sadhasivam, T., Kim, H., Park, J.-H. \& Jung, H.-Y. 2016. Carbon free $\mathrm{SiO} 2-\mathrm{SO} 3 \mathrm{H}$ supported $\mathrm{Pt}$ bifunctional electrocatalyst for unitized regenerative fuel cells. International Journal of Hydrogen Energy 41(45): 20650-20659.

St. John, S., Dutta, I. \& P. Angelopoulos, A. 2010. Synthesis and characterization of electrocatalytically active platinum atom clusters and monodisperse single crystals. The Journal of Physical Chemistry C 114(32): 1351513525.

Swider-Lyons, K. E. \& Campbell, S. A. 2013. Physical chemistry research toward proton exchange membrane fuel cell advancement. The Journal of Physical Chemistry Letters 4(3): 393-401.

Tian, G.-L., Zhao, M.-Q., Yu, D., Kong, X.-Y., Huang, J.-Q., Zhang, Q. \& Wei, F. 2014. Nitrogen-doped graphene/carbon nanotube hybrids: in situ formation on bifunctional catalysts and their superior electrocatalytic activity for oxygen evolution/reduction reaction. Small 10(11): 2251-2259.

Unni, S. M., Illathvalappil, R., Bhange, S. N., Puthenpediakkal, H. \& Kurungot, S. 2015. Carbon nanohorn-derived graphene nanotubes as a platinum-free fuel cell cathode. ACS Applied Materials \& Interfaces 7(43): 2425624264.

Vesborg, P. C. K. \& Jaramillo, T. F. 2012. Addressing the terawatt challenge: scalability in the supply of chemical elements for renewable energy. RSC Advances 2(21): 7933.

Wang, Z., Zuo, P., Fan, L., Han, J., Xiong, Y. \& Yin, G. 2016. Facile electrospinning preparation of phosphorus and nitrogen dual-doped cobalt-based carbon nanofibers as bifunctional electrocatalyst. Journal of Power Sources 311: 68-80.

Won, J.-E., Kwak, D.-H., Han, S.-B., Park, H.-S., Park, J.-Y., Ma, K.-B., Kim, D.-H. \& Park, K.-W. 2018. PtIr/Ti ${ }_{4} \mathrm{O}_{7}$ as a bifunctional electrocatalyst for improved oxygen reduction and oxygen evolution reactions. Journal of Catalysis 358: 287-294.

Ye, F., Xu, C., Liu, G., Li, J., Wang, X., Du, X. \& Lee, J. K. 2018. A novel PtRuIr nanoclusters synthesized by selectively electrodepositing Ir on PtRu as highly active bifunctional electrocatalysts for oxygen evolution and reduction. Energy Conversion and Management 155: 182-187.

Yim, S.-D., Park, G.-G., Sohn, Y.-J., Lee, W. Y., Yoon, Y.G., Yang, T. H., Um, S., Yu, S.-P. \& Kim, C.-S. 2005. 
Optimization of PtIr electrocatalyst for PEM URFC. International Journal of Hydrogen Energy 30: 13451350.

Zamel, N. 2016. The catalyst layer and its dimensionality - A look into its ingredients and how to characterize their effects. Journal of Power Sources 309: 141-159.

Zhang, M., Hu, L., Lin, G. \& Shao, Z. 2012. Honeycomb-like nanocomposite Ti-Ag-N films prepared by pulsed bias arc ion plating on titanium as bipolar plates for unitized regenerative fuel cells. Journal of Power Sources 198: 196-202.

Ahmad Mohamad Pauzi, Umi Azmah Hasran*, Sahriah Basri, Nabila A. Karim

Fuel Cell Institute,

Universiti Kebangsaan Malaysia, 43600 UKM Bangi, Selangor, Malaysia.

*Corresponding author;

email: umi.h@ukm.edu.my

Received date: $4^{\text {th }}$ June 2018

Accepted date: $13^{\text {th }}$ September 2018

Online first date: $1^{\text {st }}$ October 2018

Published date: $30^{\text {th }}$ November 2018 